\title{
Penggunaaan Zeolit untuk Mempertahankan Viabilitas Benih Pala (Myristica fragrans Houtt) Selama di Penyimpanan
}

\author{
The Use of Zeolite to Maintaining the Viability of The Nutmeg (Myristicafragrans Houtt) Seed \\ During Storage
}

Maisaroh Tanjung, Eni Widajati*, dan Faiza C.Suwarno

\author{
Departemen Agronomi dan Hortikultura, Fakultas Pertanian, Institut Pertanian Bogor \\ (Bogor Agricultural University), Jl. Meranti, Kampus IPB Darmaga, Bogor 16680, Indonesia \\ Telp. \& Faks. 62-251-8629353 e-mail agronipb@indo.net.id \\ *Penulis korespondensi: eny_widajati@yahoo.co.id \\ Disetujui 4 Mei 2016/ Published online 9 Mei 2016
}

\begin{abstract}
Nutmeg seeds belong to the recalcitrant groups, which require humid condition during storage. Zeolite is a volcanic deposit proven to be utilized as moisturizing ingredients. Environment condition during storage period is important factor affecting seed viability. The objective of the study was to determine the effect of the use zeolite for maintaining the viability of nutmeg seed during storage. The experiment was arranged in a Split Plot according to Completely Randomized Design with 3 replications. The main plot was the humidity levels including $H_{0}:$ dry condition (without zeolite) and $H_{1}=$ humid condition (with zeolite). The Subplot was storage period $(P)$ consisted of six levels : $P 0=0$ day, $P 1=3$ days, $P 2=6$ days, $P 3=9$ days, $P 4=12$ days, and $P 5=15$ days. The results showed that the addition of zeolite during storage could maintain nutmeg seed viability better than without zeolite. Storage conditions and storage period proved to be significantly affected on potential viability parameters with variabel germination, total viability parameters with maximum growth potential and seed vigor with speed of growth and vigor index. Storage condition of zeolite to maintain the seed moisture content increased from $34.61 \%$ to $39.69 \%$, whereas it was maintened from $27.83 \%$ to $22.86 \%$ in the storage without zeolite. High moisture content to able maintain the viability remained high, which are show the seed viability remain high until a storage period was 15 days.
\end{abstract}

Keywords: zeolite, storage condition, storage period, recalcitrant seed.

\section{ABSTRAK}

Benih pala termasuk kelompok benih rekalsitran yang membutuhkan kondisi lembab selama penyimpanan. Zeolit adalah endapan vulkanik yang dimanfaatkan sebagai bahan pelembab. Kondisi lingkungan periode penyimpanan merupakan faktor penting yang mempengaruhi viabilitas benih. Tujuan dari penelitian ini adalah untuk mengetahui pengaruh kondisi penyimpanan dengan penambahan zeolit dan periode simpan terhadap viabilitas benih pala. Percobaan disusun dalam Split Plot dengan Rancangan Acak Lengkap menggunakan tiga ulangan. Petak utama adalah kondisi simpan yaitu $H_{0}=k o n d i s i$ kering (tanpa zeolit) dan $H_{l}=$ kondisi lembab (dengan zeolit). Anak petak adalah periode simpan $(P)$ terdiri dari enam taraf : $P_{0}=$ tanpa penyimpanan $(0$ hari $), P_{1}=$ penyimpanan 3 hari, $P_{2}=$ penyimpanan 6 hari, $P_{3}=$ penyimpanan 9 hari, $P_{4}=$ penyimpanan 12 hari, $P_{5}=$ penyimpanan 15 hari. Hasil penelitian menunjukkan bahwa kondisi simpan dengan zeolit lebih baik dibandingkan dengan kondisi simpan tanpa zeolit dalam mempertahankan viabilitas benih pala. Kondisi simpan dan periode simpan terbukti berpengaruh nyata terhadap parameter viabilitas potensial dengan tolok ukur daya berkecambah, viabilitas total dengan tolok ukur potensi tumbuh maksimum, serta vigor benih dengan tolok ukur kecepatan tumbuh dan indeks vigor. Penyimpanan dengan zeolit meningkatkan kadar air benih dari $34.61 \%$ menjadi $39.69 \%$, sedangkan penyimpanan tanpa zeolit mempertahankan kadar air benih dari $27.83 \%$ menjadi $22.86 \%$. Kondisi kadar air yang tinggi dapat mempertahankan viabilitas tetap tinggi yang ditunjukkan pada viabilitas benih tetap tinggi hingga periode simpan hari-15.

Kata kunci: zeolit, kondisi simpan, periode penyimpanan, benih rekalsitran. 


\section{PENDAHULUAN}

\section{Pala (Myristica fragrans Houtt)} merupakan tanaman rempah asli Indonesia yang berasal dari Banda dan Maluku (Bapenas, 2000). Tanaman pala juga dikenal sebagai tanaman rempah yang memiliki nilai ekonomi tinggi dan multiguna. Hampir semua bagian batang maupun buahnya dapat dimanfaatkan dalam berbagai industri. Biji, fuli dan minyak pala merupakan komoditas ekspor dan digunakan dalam industri makanan, minuman, obat-obatan dan kosmetik (Nurdjannah, 2007).

Indonesia merupakan negara pengekspor pala terbesar di dunia, dengan memasok sekitar $60-75 \%$ kebutuhan pangsa pasar dunia. Potensi ini tidak diiringi dengan mutu pala Indonesia yang masih rendah dibandingkan Grenada dan negara lain. Rendahnya mutu pala tersebut disebabkan beberapa faktor diantaranya umur tanaman pala yang sudah tidak produktif, pemeliharaan jarang dilakukan, belum menggunakan bibit unggul, kelembagaan petani masih lemah dan mutu produksi rendah (Dirjenbun, 2012). Hal tersebut juga didukung dengan pernyataan Deptan (2001) bahwa komoditas pala Indonesia sebagian besar dihasilkan oleh perkebunan rakyat, yaitu sekitar 98.84\% dengan pemeliharaan yang tidak intensif.

Deptan (2001) mengadakan kegiatan pengembangan subsistem agribisnis hulu dengan kegiatan utama pengembangan industri perbenihan serta adanya perbaikan mutu bahan tanaman pada tahun 2001 - 2004. BPS (2013) juga menunjukkan data produksi pala tertinggi terjadi pada tahun 2001 yang mencapai nilai produksi sebesar 76.9 ribu ton. Tahun 2005 hingga tahun 2013 Indonesia mengalami fluktuasi produksi pala. Penurunan produksi pala tersebut menjadi kendala untuk memenuhi permintaan dan standar pasar internasional. Oleh sebab itu, perlu adanya teknologi yang dapat meningkatkan pengusahaan produksi pala. Salah satu komponen terpenting dalam peningkatan produksi pala adalah ketersedian benih bermutu. Ketersediaan benih bermutu dapat diupayakan dengan menjaga viabilitas benih tetap tinggi selama di penyimpanan. Kendala ketersediaan pala yaitu benih pala termasuk benih rekalsitran. Benih rekalsitran sangat cepat mengalami penurunan viabilitas. Hal ini menjadi kendala dalam pemilihan kondisi simpan dan lama penyimpanan (Justice dan Bass, 2002).

Kondisi simpan yang optimum diharapkan dapat mempertahankan viabilitas benih tetap tinggi selama di penyimpanan.. Penambahan zeolit pada kemasan merupakan salah satu solusi untuk mempertahankan kodisi simpan yang optimum. Hal ini disebabkan dengan penggunaan zeolit, $\mathrm{RH}$ lingkungan penyimpanan lebih terkendali sehingga kadar air benih dipertahankan tetap tinggi (Saputra et al., 2009). Hasil penelitian Mira (1999) menunjukkan bahwa zeolit dimanfaatkan sebagai media pelembab dalam penyimpanan benih lengkeng dengan persentase daya berkecambah $81.20 \%$ dibandingkan dengan media serbuk gergaji dengan daya berkecambah $74.13 \%$. Keunggulan lain dari zeolit yaitu sifat porous sehingga memungkinkan pertukaran oksigen lebih baik sehingga menjamin benih tetap melakukan respirasi dengan baik selama di penyimpanan (Hartati et al., 2001).

Penelitian ini bertujuan untuk mengetahui pengaruh penggunaan zeolit dalam mempertahankan viabilitas benih pala selama di penyimpanan.

\section{BAHAN DAN METODE}

Penelitian ini dilaksanakan pada bulan Desember 2014 sampai dengan bulan April 2015. Lokasi percobaan bertempat di green house Kebun Percobaan Leuwikopo dan Laboratorium Benih Departemen Agronomi dan Hortikultura, Fakultas Pertanian, Institut Pertanian Bogor.

Bahan yang digunakan adalah benih pala yang dipanen pada awal bulan Desember 2014 yang berasal dari desa Wakal, Ambon. Kemasan yang digunakan yaitu plastik mika transparan berukuran $22 \mathrm{~cm} \times 11 \mathrm{~cm} \times 9 \mathrm{~cm}$, zeolit, fungisida berbahan aktif mankozeb $80 \%$, dan pasir Cimangkok sebagai media kecambah. Alat yang digunakan adalah mesin gerinda tipe bench grinder MD-150, mesin pengiris pala, staples, cawan kadar air, desikator, gembor, oven, timbangan digital, bak pengecambah ukuran $38 \mathrm{~cm}$ x $32 \mathrm{~cm} \times 10 \mathrm{~cm}$, alat tulis, dan label.

Percobaan ini menggunakan Rancangan Split Plot dengan tiga ulangan. Kondisi simpan sebagai petak utama dan lamanya periode simpan sebagai anak petak dengan masing-masing perlakuan diulang tiga kali. Petak utama yaitu kondisi simpan (K) terdiri dari dua taraf yaitu $\mathrm{H}_{0}=$ kondisi kering (tanpa zeolit), $\mathrm{H}_{1}=$ kondisi lembab (dengan zeolit). Anak petak yaitu periode penyimpanan $(\mathrm{P})$ terdiri dari enam taraf taraf: $\mathrm{P}_{0}=$ tanpa penyimpanan $(0$ hari $), \mathrm{P}_{1}=$ penyimpanan 3 hari , $\mathrm{P}_{2}=$ penyimpanan 6 hari, $\mathrm{P}_{3}=$ penyimpanan 9 hari, $\mathrm{P}_{4}=$ penyimpanan 12 hari, $\quad \mathrm{P}_{5}=$ penyimpanan 15 hari. Percobaan ini terdiri dari 36 satuan percobaan dan tiap satuan percobaan terdiri dari 30 benih, sehingga total benih yang dibutuhkan untuk tiga ulangan yaitu 1080 benih. Data yang diperoleh dianalisis dengan uji $\mathrm{F}$ untuk 
melihat ada tidaknya perbedaan antar perlakuan. Apabila terdapat pengaruh yang nyata pada taraf 5 \% maka dilakukan uji lanjut DMRT (Duncan Multiple Range Test) untuk mengetahui perlakuan yang terbaik. Pengolahan data menggunakan software SAS dan Microsoft Excel.

Benih pala dipisahkan dari daging buah dan fuli buah, kemudian disortir untuk memilih benih yang terbaik secara visual. Hasil dari benih yang disortir tersebut kemudian direndam dengan fungisida dengan konsentrasi $10 \mathrm{gL}^{-1}$ selama 30 menit. Benih kemudian dihamparkan untuk diangin-anginkan selama 24 jam. Benih kembali dilakukan pemberian fungisida $10 \mathrm{~g}$ yang dicampur dengan $5 \mathrm{~g}$ talek untuk pengenceran fungisida. Konsentrasi fungisida tersebut cukup untuk seluruh benih percobaan yaitu 1080 benih. Benih yang telah dikering anginkan dan diberi fungisida kemudian dikemas dalam plastik mika transparan.

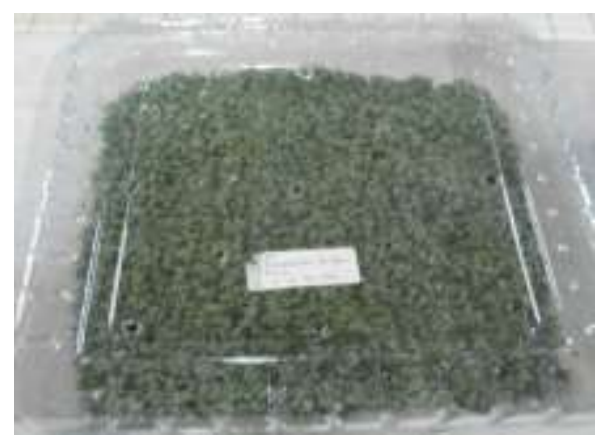

(a)

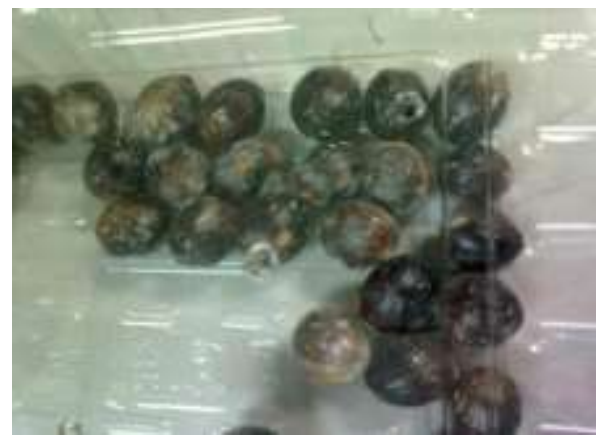

(b)

Gambar 1. Kondisi penyimpanan tanpa zeolit (a) dan dengan zeolit (b)

Kemasan plastik mika transparan berukuran $22 \mathrm{~cm}$ x $11 \mathrm{~cm}$ x $9 \mathrm{~cm}$ dapat menyimpan 30 benih dengan tambahan $1450 \mathrm{~g}$ zeolit. Zeolit dengan kadar air 20\% ditambahkan pada kemasan. Zeolit dengan kadar air $20 \%$ dibuat dengan cara menambahan air $200 \mathrm{ml} \mathrm{kg}{ }^{-1}$ zeolit. Kemasan kemudian diberi 13 lubang udara pada bagian tutup kemasan guna melancarkan sirkulasi oksigen dalam kemasan. Benih yang telah dikemas disimpan selama periode simpan yang telah ditentukan.
Benih yang telah disimpan kemudian diukur kadar airnya. Benih yang digunakan untuk pengukuran kadar air yaitu 5 butir dan 25 butir untuk dikecambahkan pada setiap ulangan. Benih yang akan dikecambahkan terlebih dahulu diberi perlakuan skarifikasi dua lubang dan diinkubasi. Perlakuan skarifikasi ini dilakukan dengan mesin gerinder listrik dengan putaran $2950 \mathrm{rpm}$. Pada saat proses skarifikasi diusahakan agar tidak merusak embrio benih. Benih yang telah diskarifikasi kemudian direndam dalam air selama 4 jam. Hal ini bertujuan untuk meningkatkan imbibisi air secara maksimal. Benih kemudian diinkubasi pada media zeolit berkadar air 50\% selama 5 hari. Selanjutnya benih dikecambahkan pada media pasir yang telah diberi fungisida $2 \mathrm{gL}^{-1}$ seminggu sebelumnya. Pengecambahan dan pengamatan viabilitas dan vigor benih dilakukan di green house Kebun Percobaan Leuwikopo.

Pengamatan dilakukan dengan mengukur kadar air, viabilitas dan vigor benih. Tolok ukur pengamatan viabilitas benih yaitu daya berkecambah dan potensi tumbuh maksimal, dan vigor benih yaitu kecepatan tumbuh dan indeks vigor. Potensi tumbuh maksimal (PTM), pengamatan dengan menghitung jumlah benih yang berkecambah baik berkecambah normal maupun abnormal hingga akhir waktu pengamatan (hari ke-100). Daya berkecambah benih (DB), pengamatan dengan menghitung jumlah kecambah normal $(\mathrm{KN})$ pada hitungan pertama (hari ke-50) dan hitungan kedua (hari ke- 100). Kecepatan tumbuh benih $\left(\mathrm{K}_{\mathrm{CT}}\right)$, pengamatan dengan menghitung jumlah tambahan perkecambahan harian atau etmal selama kurun waktu perkecambahan. Pengamatan dimulai saat hari ke-10 setelah benih ditanam hingga 100 hari dengan interval pengamatan 5 hari sekali. Indeks vigor (IV), pengamatan dengan menghitung persentase kecambah normal yang tumbuh pada hitungan hari ke-75. Kadar air (KA), diukur dengan menggunakan metode langsung, yaitu dengan metode oven pada suhu $103 \pm 2{ }^{\circ} \mathrm{C}$ selama $17 \pm 1$ jam. Benih yang sudah dikeringkan dimasukkan ke dalam desikator selama $30-45$ menit.

\section{HASIL DAN PEMBAHASAN}

\section{Kondisi Umum Percobaan}

Benih pala disimpan dalam dua kondisi simpan yang berbeda yaitu kondisi simpan dengan tambahan zeolit dan kondisi simpan tanpa zeolit. Penyimpanan dilakukan pada suhu kamar berkisar antara $25^{\circ} \mathrm{C}$ hingga $28^{\circ} \mathrm{C}$ selama periode simpan yang telah ditentukan. Selama masa penyimpanan, 
hampir seluruh benih dalam kondisi simpan tanpa zeolit terinfeksi oleh cendawan. Sementara benih dalam kondisi simpan dengan zeolit hanya $1 \%$ dari seluruh benih yang terinfeksi cendawan. Hal ini dapat disebabkan faktor internal seperti seed born ataupun faktor eksternal seperti suhu dan kelembaban.

Benih yang telah disimpan kemudian ditanam untuk pengamatan selanjutnya. Penanaman dilakukan di green house selama 100 hari. Pada bulan pertama perkecambahan, media perkecambahan berlumut akibat kelembaban yang tinggi. Curah hujan pada bulan Januari 2015 juga meningkat 250-350 mm (BMKG 2015). Benih kemudian pindah tanam pada media baru dengan kondisi benih sudah berakar. Selama masa perkecambahan, benih berkecambah normal dan tidak terserang hama maupun penyakit hingga akhir pengamatan.

\section{Faktor Kondisi Simpan dan Periode Simpan}

Pada dasarnya, benih akan mengalami kemunduran atau deteriorasi selama masa penyimpanan yang disebabkan oleh beberapa faktor. Proses deteriorasi tersebut tidak dapat dicegah atau dihindari, melainkan hanyalah mengurangi kecepatannya. Salah satu usaha untuk mengurangi kecepatan deteriorasi tersebut dapat dilakukan dengan cara mengoplimalisasikan kondisi simpan dan periode simpan yang tepat. Kondisi simpan optimal dan lama periode simpan yang tepat dapat mempertahankan viabilitas benih selama masa simpannya. Rekapitulasi hasil sidik ragam semua tolok ukur yang diamati berdasarkan hasil percobaan dapat dilihat pada Tabel 1 .

Tabel 1. Rekapitulasi hasil analisis ragam pada pengaruh kondisi simpan dan periode simpan terhadap perkecambahan benih pala

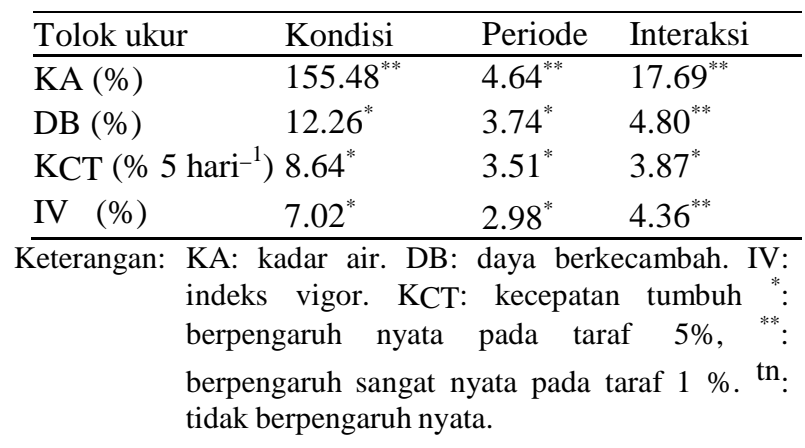

Kondisi simpan dan periode simpan berpengaruh sangat nyata terhadap kadar air benih. Kondisi simpan dan periode simpan juga berpengaruh nyata terhadap parameter viabilitas benih. Tolok ukur yang diamati untuk parameter viabilitas benih yaitu daya berkecambah (DB) dan potensi tumbuh maksimum (PTM) yang mana memiliki nilai hasil yang sama dalam percobaan. Kondisi simpan dan periode simpan berpengaruh nyata terhadap parameter vigor kekuatan tumbuh yang diukur dengan tolok ukur indeks vigor (IV) dan berpengaruh nyata terhadap kecepatan tumbuh $\left(\mathrm{K}_{\mathrm{CT}}\right)$. Interaksi antar perlakuan berpengaruh sangat nyata terhadap semua tolok ukur yang diamati.

Kondisi benih yang disimpan dengan zeolit memiliki kelembaban yang akan tetapterjaga dengan sifat zeolit. Kondisi benih untuk berespirasi juga terjaga karena ruang antar molekul zeolit dengan ukuran 2 - 4 mesh memungkinkan udara masuk dan keluar dengan kondisi yang tidak berlebihan. Hal tersebut berbeda pada saat benih dalam kondisi kering tanpa zeolit. Suhu dan RH yang semakin meningkat mengakibatkan benih berespirasi terus menerus akibat penyimpanan yang dilakukan dalam kondisi yang tidak optimum. Perbedaan kondisi ini mengakibatkan benih dengan tambahan zeolit dapat mempertahankan kadar air benih tetap stabil dibandingkan dengan benih tanpa zeolit. Hal ini juga didukung dengan sifat zeolit yang dapat mempertahankan air memberikan masa simpan benih yang lebih lama dibandingkan dengan peyimpanan tanpa zeolit.

Berdasarkan data hasil percobaan diatas, lamanya periode simpan juga berpengaruh nyata pada semua peubah yang diamati. Semakin lama periode simpan suatu benih maka akan terjadi pula kemunduran viabilitas benih. Hal ini terjadi akibat adanya penuaan pada benih yang terus melakukan metabolisme berkelanjutan selama masa penyimpanan. Hasil penelitian Samjaya et al. (2010) menunjukkan bahwa penurunan mutu benih karet berkorelasi positif dengan lamanya periode simpan benih karena adanya proses respirasi secara terus menerus yang mengakibatkan hampir semua cadangan makanan termasuk protein, lemak, dan karbohidrat berkurang selama benih disimpan.

\section{Pengamatan Kadar Air}

Kadar air merupakan suatu peubah yang sangat mempengaruhi viabilitas benih selama masa penyimpanan karena kadar air berbanding lurus dengan laju respirasi benih. Kadar air dan kandungan cadangan makanan selama dalam penyimpanan akan mengalami penurunan seiring dengan metabolisme yang berkelanjutan (Tabel 2). 
Bul. Agrohorti 4 (2): 202-209 (2016)

Tabel 2. Pengaruh periode dan kondisi simpan benih terhadap kadar air (\%) benih pala

\begin{tabular}{lllllll}
\hline \multirow{2}{*}{ Kondisi simpan } & \multicolumn{5}{c}{ Periode simpan } \\
\cline { 2 - 7 } & \multicolumn{1}{c}{0} & 3 & 6 & 9 & 12 & 15 \\
\hline Dengan zeolit & $25.96 \mathrm{ef}$ & $33.3 \mathrm{bcd}$ & $34.61 \mathrm{bc}$ & $37.4 \mathrm{ab}$ & $35.5 \mathrm{ab}$ & $39.69 \mathrm{a}$ \\
Tanpa zeolit & $27.83 \mathrm{def}$ & $29.21 \mathrm{cde}$ & $24.25 \mathrm{ef}$ & $24.84 \mathrm{ef}$ & $22.77 \mathrm{f}$ & $22.86 \mathrm{f}$ \\
\hline
\end{tabular}

Keterangan: Angka-angka yang diikuti oleh huruf yang sama berarti tidak berbeda nyata pada taraf uji 5\% (uji selang berganda Duncan).

Berdasarkan pada Tabel 2 terlihat bahwa kadar air benih yang disimpan menggunakan zeolit menunjukkan hasil yang nyata lebih tinggi dibandingkan dengan kondisi simpan tanpa zeolit mulai dari hari ke-6 penyimpanan. Benih yang disimpan dalam kondisi dengan zeolit mengalami peningkatan kadar air. Peningkatan kadar air benih disebabkan kondisi simpan yang tetap lembab. Hal tersebut diharapkan karena dapat menjaga kadar air benih tetap tinggi selama di penyimpanan. Kondisi kadar air yang tinggi menghasilkan nilai daya berkecambah yang tinggi pula (Tabel 3). Kadar air benih dalam kondisi simpan dengan zeolit stabil pada periode hari ke-9 hingga hari ke-15. Sementara untuk kadar air pada kondisi simpan tanpa zeolit semakin menurun hingga periode hari ke-15 dan menghasilkan daya berkecambah nyata lebih rendah dibandingkan dengan kondisi simpan dengan zeolite.

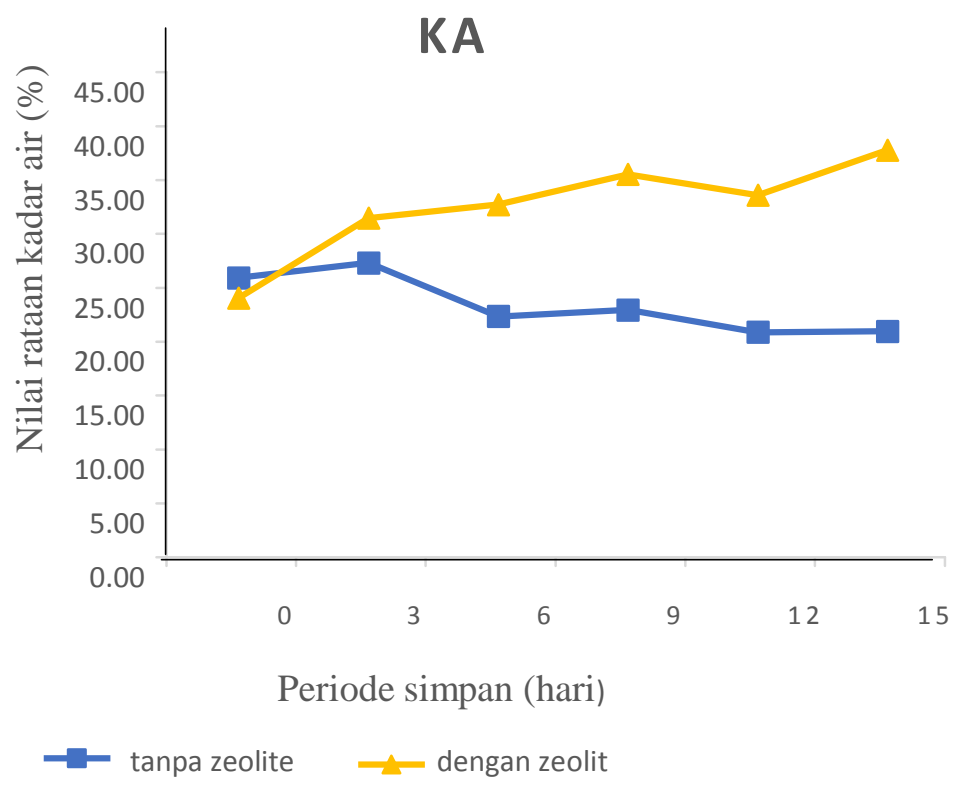

Gambar 2. Interaksi periode simpan dan kondisi simpan terhadap kadar air benih

Hasil interaksi antara periode simpan dan kondisi simpan terhadap kadar air benih dapat dilihat pada Gambar 2. Benih pala termasuk dalam benih rekalsitran yang mengharapkan kondisi simpan dengan kadar air tetap tinggi. Kadar air pada kondisi simpan dengan zeolit terus meningkat seiring dengan lamanya periode simpan dan sebaliknya pada kondisi tanpa zeolit terus mengalami penurunan kadar air.

\section{Pengamatan Viabilitas Potensial dan Viabilitas Total}

Interaksi antara kondisi simpan dan periode simpan berpengaruh nyata terhadap daya berkecambah dan potensi tumbuh maksimum.
Nilai daya berkecambah memiliki nilai yang sama dengan potensi tumbuh maksimum. Hal tersebut dikarenakan semua benih yang tumbuh mencapai kecambah normal pada akhir pengamatan. Hasil daya berkecambah benih pada setiap kondisi simpan dengan zeolit dan tanpa zeolit pada periode hari ke-0 dan hari ke-6 tidak berbeda nyata. Daya berkecambahan dan potensi tumbuh maksimum benih tertinggi terdapat pada kondisi simpan dengan zeolit dengan periode penyimpanan hari ke-9, persentase kecambah rataan $23.55 \%$. Berbeda dengan hasil daya kecambah pada kondisi simpan tanpa zeolit tidak berbeda nyata pada setiap periode simpan. Hasil data diatas masih jauh untuk mencapai daya berkecambah $50 \%$ dari total benih yang ditanam. 
Hal tersebut erat kaitannya pada kadar air benih selama di penyimpanan.

Pada Tabel 2 terlihat bahwa kadar air stabil dari periode hari ke-9 hingga hari ke-15. Semakin optimum kondisi simpan akan berpengaruh pada kadar air dan berkaitan erat dengan hasil daya berkecambah benih. Hasil penelitian Febryan (2014) terkait pengaruh media tanam dan teknik skarifikasi benih juga masih menunjukkan angka daya berkecambah pala tertinggi yaitu hanya $2.67 \%$ dari total hasil percobaan. Kendala yang dihadapi dalam perkecambahan yaitu karena adanya beberapa faktor baik dalam penyimpanan maupun pada saat kondisi di lapang, seperti suhu, kondisi RH, daya vigor benih, dan sebagainya.

Tabel 3. Pengaruh periode simpan dan kondisi simpan terhadap daya berkecambah benih (\%)

\begin{tabular}{|c|c|c|c|c|c|c|}
\hline \multirow{2}{*}{ Kondisi simpan } & \multicolumn{6}{|c|}{ Periode simpan } \\
\hline & 0 & 3 & 6 & 9 & 12 & 15 \\
\hline Dengan zeolit & 5.73defg & $15.34 \mathrm{bc}$ & $2.83 \mathrm{efg}$ & $23.55 a$ & $12.96 \mathrm{bcd}$ & $16.26 \mathrm{ab}$ \\
\hline Tanpa zeolit & 6.60de & 4.71defg & 6.60def & 6.60defg & $2.83 \mathrm{efg}$ & $2.83 \mathrm{efg}$ \\
\hline
\end{tabular}

Keterangan : Angka-angka yang diikuti oleh huruf yang sama berarti tidak berbeda nyata pada taraf uji 5\% (uji selang berganda Duncan).

Tabel 4 terlihat bahwa selama penyimpanan dengan tambahan zeolit, beberapa benih mengalami pertumbuhan apokol. Munculnya apokol tersebut terjadi karena kondisi simpan yang optimum untuk berkecambah. Zeolit merupakan media penyimpanan serta dapat juga sebagai media perkecambahan benih. Hasil penelitian Hartati et al. (2001) zeolit merupakan media yang terbaik untuk perkecambahan benih duku karena zeolit memiliki kapasitas tukar kation (KTK) paling tinggi dibanding dengan media campuran dan pasir. Tingginya nilai KTK zeolit mengakibatkan proses pertukaran ion cepat terjadi. Semakin cepat pertukaran ion maka akan semakin cepat pula terjadi proses metabolisme benih. Sementara hasil penelitian Mira (1999) zeolit digunakan sebagai media simpan menunjukkan hasil yang lebih baik dengan daya berkecambah $81.20 \%$ dibandingkan dengan media serbuk gergaji dengan daya berkecambah $74.13 \%$. Selain itu dengan media zeolit memberikan vigor kekuatan benih terbaik dibandingkan dengan media serbuk gergaji.

Tabel 4 Persentase benih yang telah muncul apokol selama masa penyimpanan

\begin{tabular}{|c|c|c|c|c|c|c|}
\hline \multirow{2}{*}{ Kondisi simpan } & \multicolumn{6}{|c|}{ Periode simpan } \\
\hline & 0 & 3 & 6 & 9 & 12 & 15 \\
\hline Dengan zeolit & 0 & 0 & 0 & 16 & 16 & 24 \\
\hline Tanpa zeolit & 0 & 0 & 0 & 0 & 0 & 0 \\
\hline
\end{tabular}

Apokol mulai muncul pada periode penyimpanan hari ke-9. Ini menunjukkan bahwa benih pala dapat disimpan dengan menggunakan zeolit selama 15 hari dengan viabilitas yang masih tinggi. Munculnya apokol tersebut terjadi karena kondisi penyimpanan yang optimum untuk berkecambah. Benih yang disimpan dengan kondisi kering tidak mengalami pemunculan apokol dan bahkan menurunkan viabilitas benih, ditunjukkan pada rendahnya daya berkecambah dan indeks vigor.

\section{Pengamatan Vigor Benih}

Kecepatan tumbuh benih merupakan indikator untuk mengetahui vigor benih. Hasil penelitian ini menunjukkan bahwa penurunan kecepatan berkecambah sejalan dengan waktu penyimpanan. Semakin lama benih disimpan menyebabkan kecepatan tumbuh semakin rendah. Kecepatan tumbuh benih mulai terlihat nyata tanpa zeolit yang menurun pada periode hari ke15. Pada Tabel 2, zeolit mampu mempertahankan kadar air tetap tinggi hingga hari ke-15 penyimpanan. Kadar air yang tinggi tersebut juga dapat menghasilkan indeks vigor yang tinggi pula.

Kecepatan tumbuh benih pada kondisi simpan tanpa zeolit tidak berbeda nyata dari periode hari ke-0 hingga hari ke-15 penyimpanan. Hal ini disebabkan kondisi benih dengan kadar air menurun seiring bertambahnya periode penyimpanan. Benih rekalsitran yang telah mengalami penurunan kadar air mengakibatkan penurunan viabilitas, sehingga kecepatan viablitasnya juga mengalami penurunan (Tabel 5). 
Tabel 5. Pengaruh periode simpan dan kondisi simpan terhadap kecepatan tumbuh benih $\left(\%\right.$ etmal $\left.^{-1}\right)$

\begin{tabular}{lcccccc}
\hline \multirow{2}{*}{ Kondisi simpan } & \multicolumn{5}{c}{ Periode simpan } \\
\cline { 2 - 7 } & 0 & 3 & 6 & 9 & 12 & 15 \\
\hline Dengan zeolite & $0.0154 \mathrm{c}$ & $0.0162 \mathrm{c}$ & $0.0152 \mathrm{c}$ & $0.0183 \mathrm{a}$ & $0.0162 \mathrm{c}$ & $0.0178 \mathrm{~b}$ \\
Tanpa zeolite & $0.0155 \mathrm{c}$ & $0.0153 \mathrm{c}$ & $0.0154 \mathrm{c}$ & $0.0154 \mathrm{c}$ & $0.0152 \mathrm{c}$ & $0.0152 \mathrm{c}$ \\
\hline
\end{tabular}

Keterangan : Angka-angka yang diikuti oleh huruf yang sama berarti tidak berbeda nyata pada taraf uji 5\% (uji selang berganda Duncan).

Hasil penelitian Suzanna (1999) pada benih karet menunjukkan bahwa pada tingkat kadar air awal $39-41 \%$ kecepatan tumbuh $5.4 \%$ etmal $^{-1}$ dan laju pertumbuhan kecambah 488 $\mathrm{mg}$ kecambah $^{-1}$. Terjadinya penurunan kecepatan tumbuh $4.68 \%$ etmal $^{-1}$ dan laju pertumbuhan kecambah benih (382 mg kecambah ${ }^{-1}$ ) dimulai pada kadar air 26-29\%. Pada kadar air 21-24\% kecepatan tumbuh dan laju pertumbuhan kecambah menurun menjadi $3.94 \%$ etmal $^{-1}$ dan $326 \mathrm{mg} \mathrm{kecambah}^{-1}$.

Indeks vigor juga merupakan indikator penentu vigor benih. Indeks vigor tidak berbeda jauh dengan tolok ukur $\mathrm{K}_{\mathrm{CT}}$ yang dipengaruhi oleh kadar air benih. Semakin cepat benih mengalami penurunan kadar air maka semakin rendah indeks vigor benih yang dihasilkan. Pengaruh periode simpan dan kondisi simpan terhadap indeks vigor benih terlihat pada Tabel 6 .

Pada kondisi tanpa zeolit indeks vigor tidak berbeda nyata pada setiap periode simpan. Indeks vigor pada periode hari ke-9 dan hari ke-12 kondisi simpan dengan zeolit berbeda nyata dengan kondisi simpan tanpa zeolit. Indeks vigor yang tinggi menunjukkan benih berkecambah lebih cepat. Hal tersebut terlihat pada Tabel 6 yang menunjukkan indeks vigor terbaik terjadi pada penyimpanan zeolit hari ke-9 dan berkecambah lebih cepat dari periode lainya (Tabel 6).

Tabel 6. Pengaruh periode simpan dan kondisi simpan terhadap indeks vigor benih (\%)

\begin{tabular}{|c|c|c|c|c|c|c|}
\hline \multirow[b]{2}{*}{ Kondisi simpan } & \multicolumn{6}{|c|}{ Periode simpan } \\
\hline & 0 & 3 & 6 & 9 & 12 & 15 \\
\hline Dengan zeolite & $4.71 \mathrm{~cd}$ & $8.71 \mathrm{bcd}$ & $2.83 \mathrm{~d}$ & $21.12 \mathrm{a}$ & $12.25 b c$ & $16.26 \mathrm{ab}$ \\
\hline Tanpa zeolite & $6.60 \mathrm{~cd}$ & $6.60 \mathrm{~cd}$ & $6.60 \mathrm{~cd}$ & $6.60 \mathrm{~cd}$ & $2.83 \mathrm{~d}$ & $2.83 \mathrm{~d}$ \\
\hline
\end{tabular}

Keterangan : Angka-angka yang diikuti oleh huruf yang sama berarti tidak berbeda nyata pada taraf uji 5\% (uji selang berganda Duncan).

\section{KESIMPULAN}

Kondisi simpan dengan zeolit lebih baik dibandingkan dengan kondisi simpan tanpa zeolit dalam mempertahankan viabilitas benih pala. Kondisi simpan dan periode simpan terbukti berpengaruh nyata terhadap parameter viabilitas potensial dengan tolok ukur daya berkecambah, viabilitas total dengan tolok ukur potensi tumbuh maksimum, serta vigor benih dengan tolok ukur kecepatan tumbuh dan indeks vigor. Penyimpanan dengan zeolit mempertahankan kadar air benih tetap tinggi dari $34.61 \%$ menjadi $39.69 \%$, sedangkan penyimpanan tanpa zeolit menurunkan kadar air benih dari $27.83 \%$ menjadi $22.86 \%$. Kondisi kadar air yang tinggi dapat mempertahankan viabilitas tetap tinggi yang ditunjukkan pada periode hari ke-9 dengan daya berkecambah $23.33 \%$, kecepatan tumbuh 0.0018 $\%$ etmal $^{-1}$, dan indeks vigor $21.12 \%$.

\section{DAFTAR PUSTAKA}

[BAPENAS] Badan Perencanaan Pembangunan Nasional. 2000. Pala (Myristica fragan Houtt). Prihatman K, editor. Jakarta (ID): Bapenas.

[BBPPTP] Balai Besar Perbenihan dan Proteksi Tanaman Perkebunan. 2014. Kriteria Pembibitan Pala. Ambon (ID): Direktorat Jendral Perkebunan.

2013. Pembibitan Pala. Ambon (ID): Direktorat Jendral Perkebunan.

2013. Skarifikasi untuk Benih Pala. Ambon (ID): Direktorat Jendral Perkebunan.

[BMKG] Badan Meteorologi Klimatologi dan Geofisika. 2015. Data Ikli Bulanan Tahun 2015. Bogor (ID): BMKG

[BPS] Badan Pusat Statistik. 2013. Produksi Perkebunan Rakyat menurut Jenis Tanaman. www.bps.go.id 
[Deptan] Departemen Pertanian. 2001. Penjabaran Program dan Kegiatan Pertanian tahun 2001-2004. Subsektor Perkebunan Bab V. Jakarta (ID): Departemen Pertanian.

[Dirjenbun] Direktorat Jendral Perkebunan. 2012. Pedoman Teknis Perluasan Tanaman Pala Tahun 2012.

Jakarta (ID): Direktorat Jendral Perkebunan. Kementrian Pertanian.

Fahmi ZI. 2013. Media Tanam Sebagai Faktor Eksternal Yang Mempengaruhi Pertumbuhan Tanaman.

Surabaya (ID): Balai Besar Perbenihan dan Proteksi Tanaman Perkebunan Surabaya.

Febriyan DG. 2014. Pengaruh teknik skarifikasi fisik dan media perkecambahan terhadap daya berkecambah benih pala (Myristica fragrans Houtt) [skripsi]. Bogor (ID): Institut Pertanian Bogor.

Hartati U, Faiza CS, dan Suwardi. 2001. Pengaruh zeolit terhadap perkecambahan benih duku (Lansium domesticum Correa). Prosiding Seminar Nasional Zeolit II "Peningkatan Pendayagunaan Zeolit dalam Industri, Agribisnis, dan Lingkungan. 21 Agustus 2001. Bandung. Bogor (ID): Institut Pertanian Bogor. Hartawan R dan Yulistiati N. 2012. Penetapan peubah utama kualitas benih karet dalam penyimpanan dengan metode sidik lintas. Jurnal Ilmiah Universitas Batanghari Jambi Edisi Kuhusus. Hal: 71-76.

Justice OL dan Bass LN. 2002. Prinsip dan Praktek Penyimpanan Benih. Roesli R. penerjemah. Jakarta (ID): PT Raja Grafindo Persada. Terjemahan dari: Principle adn Practices of Seed Storage

Kartasapoetra AG. 1986. Teknologi Benih. Jakarta (ID): PT Bina Aksara
Mira FR. 1999. Pengaruh suhu simpan, media simpan dan periode konservasi terhadap viabilitas benih lengkeng (Nephelium longan Cambess.) [skripsi]. Bogor (ID) : Institut Pertanian Bogor.

Nurdjannah N. 2007. Teknologi Pengolahan Pala. Bogor (ID): Balai Besar Penelitian dan Pengembangan Penanganan Pascapanen Pertanian.

Pramudita L. 2014. Karakterisasi morfologi benih dan penentuan kriteria kecambah normal pala (Myristica fragrans Houtt) [skripsi]. Bogor (ID): Institut Pertanian Bogor.

Rismunandar. 1990. Budidaya dan Tataniaga Pala. Cetakan Kedua. Jakarta (ID): Penebar Swadaya.

Samjaya ZR, ZR Djafar, ZP Negara, M Hasmeda dan H Suryaningtiyas. 2010. Respirasi dan penurunan mutu benih karet selama penyimpanan. Prosiding Seminar Nasional Hasil Penelitian Bidang Pertanian "Pertanian Terintegrasi untuk Mencapai Millenium Development Goals (MDGs)". Volume I Bidang Agroekoteknologi. Fakultas Pertanian Universitas Sriwiaya. Hal 421 - 434. Palembang (ID): Universitas Sriwiaya.

Sarno H 1983. Endapan Zeolit. Penggunaan dan sebarannya di Indonesia. Bandung (ID): Direktorat

Sumberdaya Mineral Departemen Pertambangan dan Energi.

Sukarman dan Rusmin D. 2000. Penanganan Benih Rekalsitran. Buletin Plasma Nutfah 6 (1): $7-15$.

Suzanna E. 1999. Pengaruh Penurunan Kadar Air dan Penyimpanan Terhadap Perubahan Fisiologi dan Biokimiawi Benih Karet (Hevea brasiliensis) [tesis]. Program Pascasarjana. Bogor (ID): Institut Pertanian Bogor. 